\title{
Potent Antitumour Effects of Novel Pentabromobenzylisothioureas Studied on Human Glial-derived Tumour Cell Lines
}

\author{
EMANUELA PUCKO ${ }^{1}$, EWA MATYJA ${ }^{1}$, MIROSŁAWA KORONKIEWICZ ${ }^{2}$, \\ ROBERT P. OSTROWSKI ${ }^{1}$ and ZYGMUNT KAZIMIERCZUK ${ }^{3}$ \\ Departments of ${ }^{1}$ Experimental and Clinical Neuropathology, and ${ }^{3}$ Experimental Neuropharmacology, \\ Mossakowski Medical Research Centre, and ${ }^{2}$ Department of Cell Biology, \\ National Medicines Institute, Polish Academy of Sciences, Warsaw, Poland
}

\begin{abstract}
Background/Aim: Tumours of astroglial origin are the most common primary brain malignancy characterized by infiltrative growth and resistance to standard antitumour therapy. Glioma progression is thought to be related to various intracellular signal transduction pathways that involve the activation of protein kinases. Protein kinases play important roles in cell differentiation, proliferation, and survival. Recently, novel, specific inhibitors of constitutively active serine/threonine kinases and structurally similar isothiourea derivatives were suggested to induce apoptosis and inhibit proliferation in several types of human cancer cells. Materials and Methods: In this study, we examined the cytotoxic and proapoptotic activities of selected modified pentabromobenzyl isothioureas (ZKKs) in an adult human glioblastoma (T98G) and a subependymal giant cell astrocytoma cell (SEGA) line. We evaluated cell proliferation, viability, and apoptosis. Results: Two pentabromobenzyl isothiourea bromide derivatives, ZKK-13 and $N, N, N$ '-trimethyl-ZKK1 (TRIM), exhibited the most potent cytotoxic and proapoptotic efficacies against human gliomaderived cells, even at a very low concentration $(1 \mu M)$. ZKK$13(25-50 \mu M)$ inhibited cell growth by approximately $80-90 \%$ in 24 and 48 h of treatment. We showed that selected ZKKs exerted antiproliferative activity against astroglial neoplastic cells of both low- and high-grade tumour malignancy classes. No synergistic effects were detected when ZKKs were combined
\end{abstract}

This article is freely accessible online.

Correspondence to: Ewa Matyja, Department of Experimental and Clinical Neuropathology, Mossakowski Medical Research Centre, Polish Academy of Sciences, 5 Pawinskiego Str., o. Warsaw, Poland. Tel/Fax: +48 226086502, e-mail: ematyja@imdik.pan.pl

Key Words: Protein kinase inhibitors, pentabromobenzyl isothioureas, gliomas, apoptosis, anticancer therapy. with serine/threonine kinase inhibitors. Conclusion: Our findings indicated that modified ZKKs show promise for the treatment of glioma-derived brain tumours.

Gliomas are the most common primary brain tumours in adults. Most gliomas are defined as 'diffusely infiltrating', due to their ability to extensively infiltrate the surrounding brain tissue and invade perivascular and subpial spaces. They are currently molecularly defined by mutations of the genes encoding isocitrate dehydrogenase 1or 2 (IDH1/2) $(1,2)$.

The most fatal brain malignancy is glioblastoma (GBM), which comprises $15 \%$ of all intracranial tumours, accounting for $70 \%$ of neoplasms of astrocytic origin in adults. Primary, IDH wild-type GBM appears de novo (95\% GBM cases), whereas a secondary, IDH-mutant GBM (5\% GBM cases) develops from the malignant transformation of a lower grade diffuse astrocytoma (3). The vast majority of GBMs that do not show mutation of $I D H$ genes show aggressive biology and confer a poor prognosis (4). Complete tumour resection is typically impossible due to diffuse neoplastic infiltration of the surrounding brain tissue. The neoplastic cells of malignant gliomas are particularly resistant to various therapeutic interventions. The standard treatment includes surgery or biopsy, followed by radiotherapy and adjuvant chemotherapy with temozolomide; but that approach remains largely ineffective. GBM is associated with an unfavourable clinical outcome; patients with newly-diagnosed GBM consistently exhibit a median survival of less than 15 months (5).

The molecular mechanisms that underlie the unique pattern of malignant glioma growth and its aggressive nature remain unclear. GBMs are molecularly heterogeneous; therefore, it is not clear which factors may determine the clinical course or prognosis. This heterogeneity makes it difficult to guide therapeutic decisions in individual cases (6). Moreover, it is important to identify the molecular, histopathological, and genomic features of glioblastomas in 
order to understand the malignant nature of these primary brain tumours and support plans for a therapeutic strategy (7). Recent advances have been made in identifying the molecular alterations that give rise to GBMs, and these may lead to new therapeutic targets and more personalized treatment approaches $(8,9)$.

Tumour progression is considered to be related to uncontrolled, diverse, intracellular signal transduction pathways, including protein kinase-mediated signalling networks (10). Protein kinase activation plays an important role in pivotal cellular events, including cell viability, differentiation, proliferation, and malignant transformation. Thus, the development of novel protein kinase inhibitors might lead to beneficial therapies in a variety of diseases, including viral infections, inflammatory processes, and cancer (11-14).

Casein kinase 2 (CK2), a member of the serine/threonine kinase family, appears to be an important anti-apoptotic enzyme. Studies showed that CK2 was overexpressed in various neoplastic processes $(15,16)$. Therefore, CK2 inhibitors, administered alone or in combination with other drugs, may be a promising pharmacological anticancer therapy (17-19). Recently, a novel class of protein kinase inhibitors, derived from isothiourea, was shown to be active against a number of cancer cells, including human prostate adenocarcinoma (20) and leukemia (21) cell lines. However, to our knowledge, only one previous report investigated the effects of isothiourea derivatives on a malignant glioma cell line (22).

This study aimed to evaluate selected S-pentabromobenzyl isothiouronium bromide (ZKK) derivatives for their antineoplastic effects on astroglial neoplastic cells derived from tumours of low- and high-grade malignancy. Despite the structural similarity between ZKKs and typical CK2 inhibitors, such as 4,5,6,7-tetrabromo- $1 H$-benzimidazole (TBI) and 2-dimethylamino-4,5,6,7-tetrabromo- $1 H$-benzimidazole (DMAT; Figure 1), ZKKs are not specific for CK2. Previous studies showed that ZKKs also moderately inhibited other kinases that are important in cell proliferation: extracellular signal regulated kinase 8 (ERK8), protein kinase D1 (PKD1), never in mitosis A-related kinase 2 (NEK2a), serine/threonineprotein kinase pim-1 (PIM1), serine/threonine-protein kinase pim-3 (PIM3), insulin-like growth factor 1 (IGF1R), and insulin receptor (IR) (20). We decided to study the expression pattern of PKD1 in a glioma cell line during the application of ZKKs. The PKD family comprises three isoforms of a serine/threonine kinase: PKD1, PKD2, and PKD3. Dysregulation of PKD expression or activity has been shown to contribute to progression of various malignancies (23-25). Therefore, we hypothesized that PKD1 expression might be reduced in malignant glioma cells exposed to ZKKs.

Moreover, we reasoned that a combination of a CK2 inhibitor with a cytotoxic ZKK might potentiate antitumor effects. Therefore, in this study, we examined the cytotoxic and pro-apoptotic efficacy of several modified ZKK derivatives: $S-(2,3,4,5,6$-pentabromobenzyl)isothiouronium bromide (ZKK-1), N-methyl-ZKK-1 (ZKK-2), $N, N^{\prime}-$ dimethyl-ZKK-1 (ZKK-3), N,N'-diisopropyl-ZKK1 (ZKK13), and $N, N, N$ '-trimethyl-ZKK1 (TRIM). Moreover, we also tested the chloride-S-benzyl-isothiouronium (BEN) in an adult human glioblastoma (T98G) cell line, a subependymal giant cell astrocytoma (SEGA) cell line, and normal human astrocytes. We also studied the synergistic effects of ZKK-3 combined with TBI or DMAT in T98G cells. The effect of a reference agent, temozolomide, was also determined.

\section{Materials and Methods}

Tested chemicals. ZKKs were synthesized in a reaction of pentabromobenzylobromide with $\mathrm{N}$-substituted thioureas, according to previously described procedures (20). Five ZKK derivatives were used in this study: ZKK-1, ZKK-2, ZKK-3, ZKK-13 and TRIM, as well as BEN. To study synergistic effects with ZKKs, we used the two CK2 inhibitors, TBI and DMAT synthesized in our laboratory according to previously described procedures (26). The structures of these compounds are presented in Figure 1. Temozolomide (Medac, Hamburg) was used as a reference agent.

Cell line cultures and growth conditions. All experiments were performed on cell lines established from human glioblastoma (T98G) cells and SEGA cells. The T98G cell line, originally derived from a WHO grade IV adult glioblastoma, was obtained from the American Type Culture Collection (Manassas, VA, USA). T98G cells were grown in Eagle's minimum Essential medium (SigmaAldrich Chemie Gmbh, Munich, Germany) supplemented with $10 \%$ foetal bovine serum (Gibco, Invitrogen, Grand Island, NY, USA), $1 \%$ penicillin/streptomycin solution (Gibco Invitrogen), and $1 \%$ non-essential amino acids (Sigma-Aldrich Chemie Gmbh). Cultures were maintained at $37^{\circ} \mathrm{C}$, in a humidified atmosphere, with $95 \%$ air $/ 5 \% \mathrm{CO}_{2}$. The cell line derived from SEGA was kindly provided by Professor K. Kotulska from the Department of Paediatric Neurology, The Children's Memorial Heath Institute, Warsaw, Poland. SEGA specimen was originally obtained from a patient with tuberous sclerosis complex, diagnosed clinically according to the Roach criteria (The study was approved by the Committee of Bioethics of the Children's Memorial Health Institute, with written informed consent of the patient to participate in the study). The cells were cultured according to a previously published protocol (27). SEGA-derived cell lines were grown in Dulbecco's modified Eagle's medium (Gibco, Invitrogen), supplemented with $10 \%$ foetal bovine serum (Gibco, Invitrogen) and a $1 \%$ solution of penicillin/streptomycin (Gibco, Invitrogen). Cultures were maintained at $37^{\circ} \mathrm{C}$, in a humidified atmosphere, with $95 \%$ air $/ 5 \%$ $\mathrm{CO} 2$. Human astrocytes, originally obtained from ScienCell, Research Laboratories (Carlsbad, CA, USA), served as an additional control, and were grown in AM Astrocyte Medium (ScienCell), supplemented with $10 \%$ foetal bovine serum (Gibco, Invitrogen) and $1 \%$ solution of penicillin/streptomycin (Gibco, Invitrogen).

Experiments for assessing cell proliferation rates. Proliferation experiments were performed in exponentially growing T98G, SEGA, and normal astrocytes. The tested agents were dissolved 
<smiles></smiles><smiles>[R]c1nc2c(Br)c(Br)c(Br)c(Br)c2[nH]1</smiles>

$\begin{array}{ll}\text { TBI } & \mathrm{R}=\mathrm{H} \\ \text { DMAT } & \mathrm{R}=\mathrm{C}\left(\mathrm{NH}_{3}\right)_{2}\end{array}$

$$
\begin{array}{ll}
\text { ZKK-1 } & \mathrm{R}_{1}, \mathrm{R}_{2}, \mathrm{R}_{3}, \mathrm{R}_{4}=\mathrm{H} \\
\text { ZKK-2 } & \mathrm{R}_{1}=\mathrm{CH}_{3}, \mathrm{R}_{2}, \mathrm{R}_{3}, \mathrm{R}_{4}=\mathrm{H} \\
\text { ZKK-3 } & \mathrm{R}_{1}, \mathrm{R}_{3}=\mathrm{CH}_{3}, \mathrm{R}_{2}, \mathrm{R}_{4}=\mathrm{H} \\
\text { ZKK-13 } & \mathrm{R}_{1}, \mathrm{R}_{3}=\mathrm{CH}\left(\mathrm{CH}_{3}\right)_{2}, \mathrm{R}_{2}, \mathrm{R}_{4}=\mathrm{H}
\end{array}
$$$$
\text { TRIM } \mathrm{R}_{1}, \mathrm{R}_{2}, \mathrm{R}_{3}=\mathrm{CH}_{3}, \mathrm{R}_{4}=\mathrm{H}
$$<smiles></smiles>

\section{Temozolomide}<smiles>[NH]/C(N)=[SH]/N</smiles>

\section{BEN}

Figure 1. Structures of S-pentabromobenzyl isothiouronium bromides (ZKKs), selected casein kinase-2 inhibitors: 4,5,6,7-tetrabromo-1Hbenzimidazole (TBI) and 2-dimethylamino-4,5,6,7-tetrabromo-1H-benzimidazole (DMAT), temozolomide, (TZM) and chloride-S-benzylisothiouronium (BEN).

separately in dimethyl sulfoxide (DMSO; Sigma-Aldrich Chemie Gmbh) and added to the culture medium. T98G, SEGA, and normal astrocytes were seeded in $5-\mathrm{cm}$ culture plates $\left(\mathrm{Nunc}^{\mathrm{TM}}\right.$, Thermo Scientific ${ }^{\mathrm{TM}}$; Thermo Fisher Scientific, Waltham, MA, USA) and grown in medium without (control) or with ZZK or BEN. The effect of temozolomide was investigated only in the T98G cell line. The final concentrations of tested compounds in complete growth medium ranged from 10 to $100 \mu \mathrm{M}$. To study the synergistic effects of ZKKs and CK2 inhibitors, TBI and DMAT (both tested at 10 and $25 \mu \mathrm{M})$, were applied together with one of the pentabromobenzyl isothioureas (ZKK-3) that effectively inhibited proliferation and viability of $\mathrm{T} 98 \mathrm{G}$ cells.

Control cell cultures were treated with an equal volume of solvent (DMSO). The exact amount of DMSO (Sigma-Aldrich Chemie Gmbh) added to the control cells was $0.1 \%$ (v/v) during cell treatment. Media were replaced daily. The effects of the tested compounds were observed with a Nikon inverted microscope (Nikon, Tokyo, Japan).

The cells treated with the studied compounds were collected after $24 \mathrm{~h}, 48 \mathrm{~h}$, and $72 \mathrm{~h}$ for the evaluation of the proliferative rate. Three independent cultures for each group were washed with phosphate-buffered saline (PBS; Sigma-Aldrich Chemie Gmbh) and trypsinized; the collected cells were centrifuged $\left(200 \times g\right.$ at $4^{\circ} \mathrm{C}$ for $5 \mathrm{~min})$. Pellets were resuspended in PBS, and the number of cells per millilitre was determined with a Multisizer3 (Beckman Coulter, Indianapolis, IN, USA). In addition, the cells were counted directly with a haemocytometer. Each experimental group comprised three independent cultures, and each culture was tested in triplicate.
Metabolic analysis of cell viability. Cell viability was determined with a 3-(4,5-dimethylthiazol-2-yl)-2,5-diphenyl tetrazolium bromide (MTT; Sigma-Aldrich, Munich, Germany) colorimetric assay. Briefly, cells were cultured in 96-well plates $\left(\mathrm{Nunc}^{\mathrm{TM}}\right.$, Thermo Scientific ${ }^{\mathrm{TM}}$ ), with $0,1 \mu \mathrm{M}, 1 \mu \mathrm{M}, 10 \mu \mathrm{M}, 25 \mu \mathrm{M}, 50 \mu \mathrm{M}, 100 \mu \mathrm{M}$ of test compounds or DMSO (Sigma-Aldrich Chemie Gmbh) in the medium. After 24 and $48 \mathrm{~h}$, cells were incubated in culture medium supplemented with MTT at a final concentration $0.5 \mathrm{mg} / \mathrm{ml}$ for $4 \mathrm{~h}$ at $37^{\circ} \mathrm{C}$. In actively metabolizing cells, MTT is converted to formazan, detected as dark blue crystals. Next, the medium was removed, the formazan crystals were dissolved in $200 \mu \mathrm{DMSO}$, and the plate was placed on a shaking table for $15 \mathrm{~min}$. Absorbance at $570 \mathrm{~nm}$ was measured with a spectrophotometer (Epoch microplate reader; BioTek, Winooski, VT, USA). All measurements were carried out in triplicate.

Flow cytometric analysis of apoptosis. Flow cytometry was performed to detect apoptosis and necrosis. BD Pharmingen FITC Annexin V Apoptosis Detection Kit I (BD Bioscences San Jose, CA, USA) was used to quantify the percentage of cells undergoing apoptosis. After 24 or $48 \mathrm{~h}$ of treatment, cells were collected by centrifugation, washed twice in cold PBS (Sigma-Aldrich Chemie $\mathrm{Gmbh}$ ), then suspended in a binding buffer at $1 \times 10^{6}$ cells $/ \mathrm{ml}$. Aliquots $(100 \mu \mathrm{l} / \mathrm{ml})$ of the cell suspension were labelled according to the kit manufacturer's instructions. In brief, fluoresceinisothiocyanate (FITC)-conjugated annexin $\mathrm{V}$ and propidium iodide (PI) were added to the cell suspension, the mixture was vortexed, then incubated for $15 \mathrm{~min}$ at room temperature in the dark. Next, 

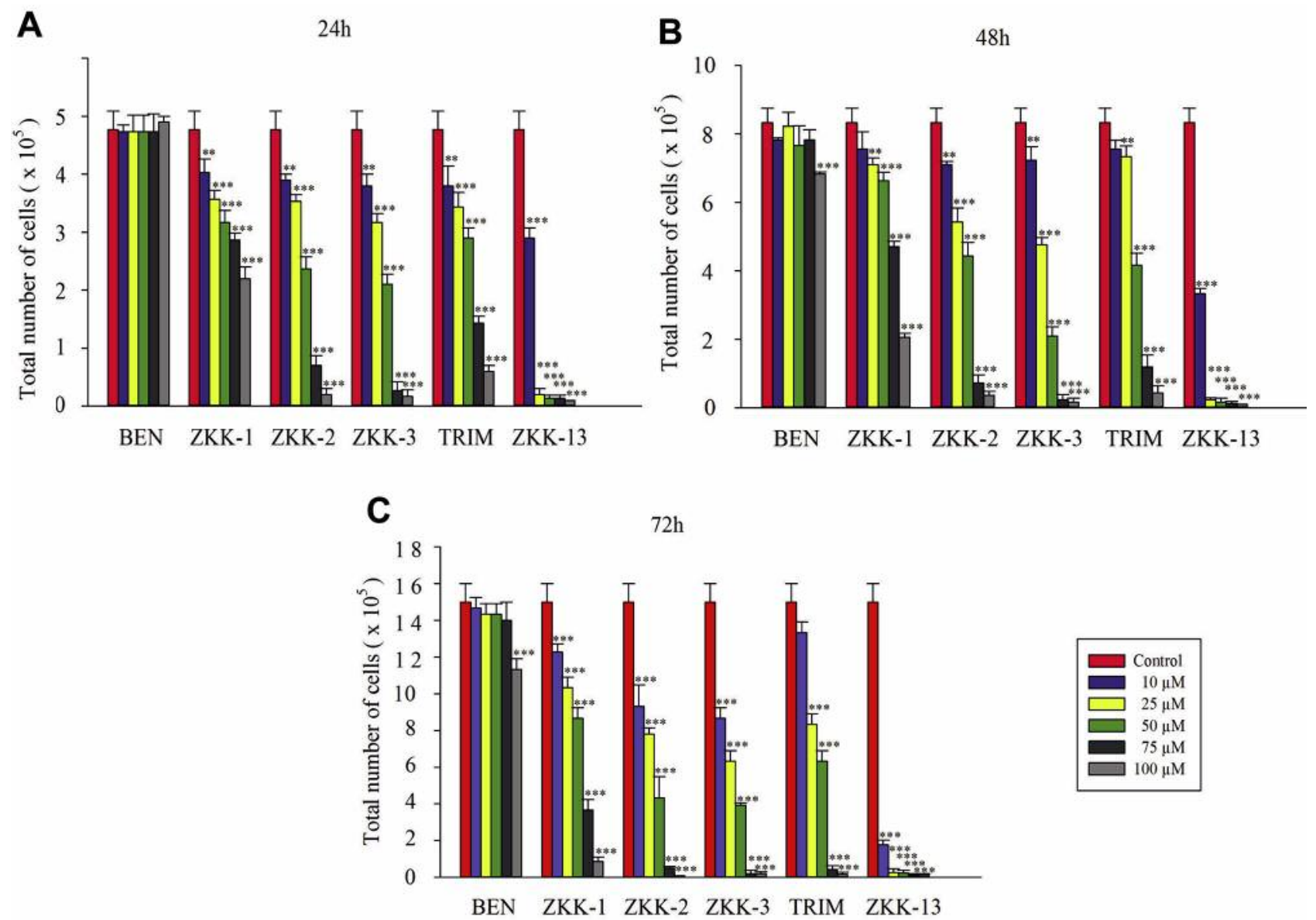

Figure 2. Effect of pentabromobenzyl isothioureas (ZKKs) on the proliferation of T98G malignant glioma cells after (A) $24 h$, (B) $48 \mathrm{~h}$, and $(C)$ $72 \mathrm{~h}$. Data are the mean \pm SD of 9 replicates. Significantly different from the control at $* * p<0.01$, and $* * * p<0.001$.

the cells were resuspended in $400 \mu \mathrm{l}$ cold binding buffer, then vortexed again, and stored on ice. Within $1 \mathrm{~h}$ of labelling, flow cytometric measurements were performed with a FACS Calibur (BD Biosciences, San Diego, CA, USA) flow cytometer.

Western blot analysis of protein modifications. Cells were suspended in PBS. Protein extracts were prepared by lysing T98G cells in radio-immunoprecipitation assay (RIPA) lysis buffer from Santa Cruz Biotechnology (Santa Cruz, CA, USA) for $5 \mathrm{~min}$. Total protein extracts were prepared, mixed with $2 \times$ Laemmli sample buffer (Sigma-Aldrich Chemie Gmbh), then boiled for $15 \mathrm{~min}$. After centrifugation at $200 \times g$ for $15 \mathrm{~min}$ at $4^{\circ} \mathrm{C}$, protein samples were resolved with sodium dodecyl sulphate polyacrylamide gel electrophoresis SDS-PAGE (BioRad Hercules, CA, USA). Next, the separated proteins were transferred to a nitrocellulose membrane (BioRad) and probed with primary rabbit anti-human antibodies specific for the cell death regulator B-cell lymphoma-2 (BCL2, 1:500; Apoptosis I Sampler Kit; BD Biosciences PKD 1 (1:1,000; Cell Signaling, Danvers, MA, USA), and phosphorylated PKD (Ser 916) (1:1,000; Cell Signaling). The primary antibodies were detected with secondary, anti-rabbit $\mathrm{IgG}$ antibody linked to horseradish peroxidase (1:2,000; Cell Signaling). Immunocomplexes were visualized with the enhanced chemiluminescence detection system Amersham ECL Western Blotting Detection Reagent (GE Healthcare Life Sciences Amersham, Buckinghamshire, UK). After the stripping step, the membranes were probed with antibody to $\beta$-actin (1:5,000; Sigma-Aldrich Chemie Gmbh) and appropriate secondary horseradish peroxidease-conjugated antibodies, prior to the use of ECL kit. The density of protein bands was determined with Image J software NIH (Bethesda, MD, USA). Results were calculated relative to corresponding $\beta$-actin bands.

Statistical analysis. All experiments were repeated at least three times. Results were analysed with one-way analysis of variance, followed by Tukey's test. Results are expressed as the mean \pm standard deviation.

\section{Results}

Effect of ZKKs on T98G malignant glioma cell proliferation. Human T98G glioblastoma cells treated with ZKK-1, ZKK-2, ZKK-3, ZKK-13, or TRIM showed significant, dose-dependent 

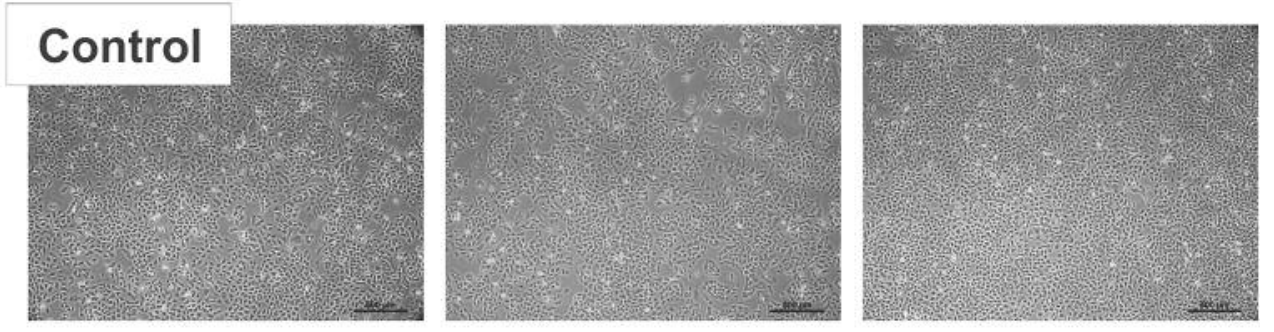

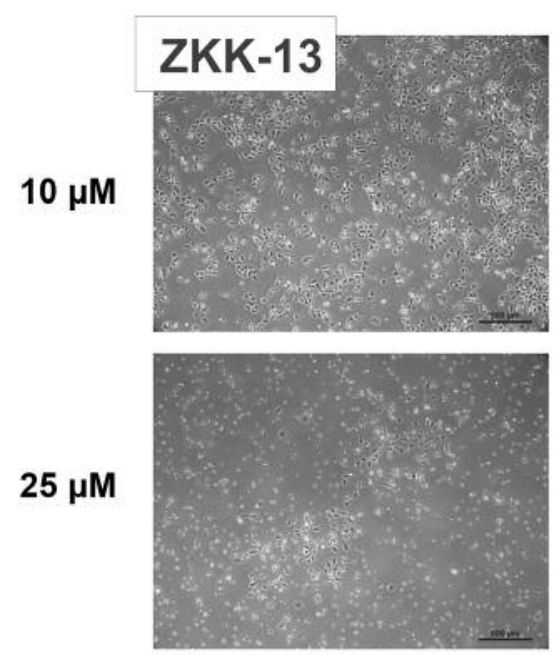

$24 \mathrm{~h}$
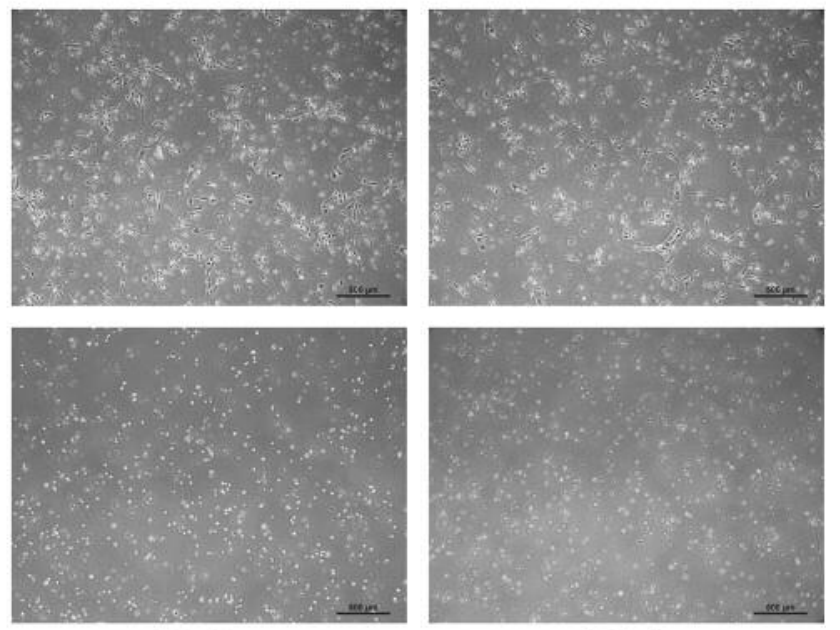

$48 \mathrm{~h}$

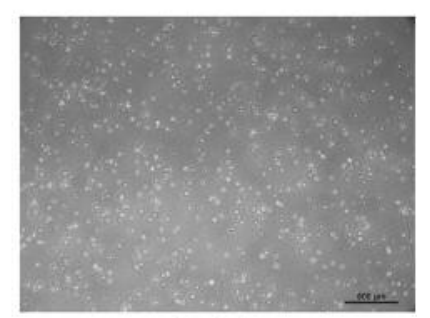

$72 \mathrm{~h}$

Figure 3. Morphological evaluation of T98G malignant glioma cell line treated with modified pentabromobenzyl isothiourea ZKK-13. Low ZKK-13 concentrations (10 and $25 \mu \mathrm{M}$ ) resulted in a decrease in cell number compared to untreated cultures.

reductions in the total number of neoplastic cells after 24, 48 , and $72 \mathrm{~h}$ of treatment compared to control cultures (Figure 2). ZKK-13 appeared to be the most effective after $24 \mathrm{~h}$ even when applied at a concentration of $25 \mu \mathrm{M}$. Morphological evaluation of $\mathrm{T} 98 \mathrm{G}$ malignant glioma cell line treated with ZKK-13 showed that application of this modified pentabromobenzylisothiourea at low concentrations (10 and $25 \mu \mathrm{M}$ ) also resulted in nearly complete eradication of viable neoplastic cells (Figure 3).

T98G glioblastoma cells were moderately resistant to BEN treatment at 10 to $75 \mu \mathrm{M}$.

Effect of ZKKs on viability of T98G malignant glioma cells. We performed an MTT metabolism assay and found that ZKKs reduced the viability of T98G glioma cells in a dosedependent manner (Figure 4). Significant reductions in T98G cell viability were observed after treatments with ZKK-2, ZKK-3, ZKK-13, and TRIM. Neoplastic cell viability was inhibited even at a very low concentration $(0.1 \mu \mathrm{M})$ of the tested compounds. Treatment with ZKK-2, ZKK-3, and TRIM reduced cell viability by an average of $45-70 \%$ at $10 \mu \mathrm{M}$ and $50 \mu \mathrm{M}$, after 24 and $48 \mathrm{~h}$, respectively. Among the tested compounds, ZKK-13 appeared to be the most effective; at $25-50 \mu \mathrm{M}$, approximately $80-90 \%$ of cells died within 24 and 48 h. ZKK-1 appeared to be less effective; it inhibited cell viability by approximately $45-75 \%$ at $10-100 \mu \mathrm{M}$ after $48 \mathrm{~h}$. BEN showed little or no effect on cell viability.

Effect of ZKKs on SEGA cell proliferation. ZKKs showed strong antiproliferative activity against the SEGA cell line (Figure 5). SEGA cells treated with ZKK-2, ZKK-3, ZKK13, and TRIM showed significant reductions in cell numbers, even at a concentration of $10 \mu \mathrm{M}$, after 48 and $72 \mathrm{~h}$, compared to untreated cultures. ZKK-13 exhibited the most potent inhibition of neoplastic cell growth; at 10, 25, and $50 \mu \mathrm{M}$, cell proliferation was nearly completely inhibited after $72 \mathrm{~h}$ of treatment. ZKK-3 also displayed a very strong cytotoxic effect against SEGA cells in vitro; at $25 \mu \mathrm{M}$ and $50 \mu \mathrm{M}, \mathrm{ZKK}-3$ reduced the total cell number by up to $90 \%$ after $72 \mathrm{~h}$ of treatment. SEGA cells were moderately resistant to BEN treatment.

Effect of ZKKs on SEGA cell viability. ZKKs inhibited the viability of cultured SEGA cells after 24 and 48 h. ZKK-2, 

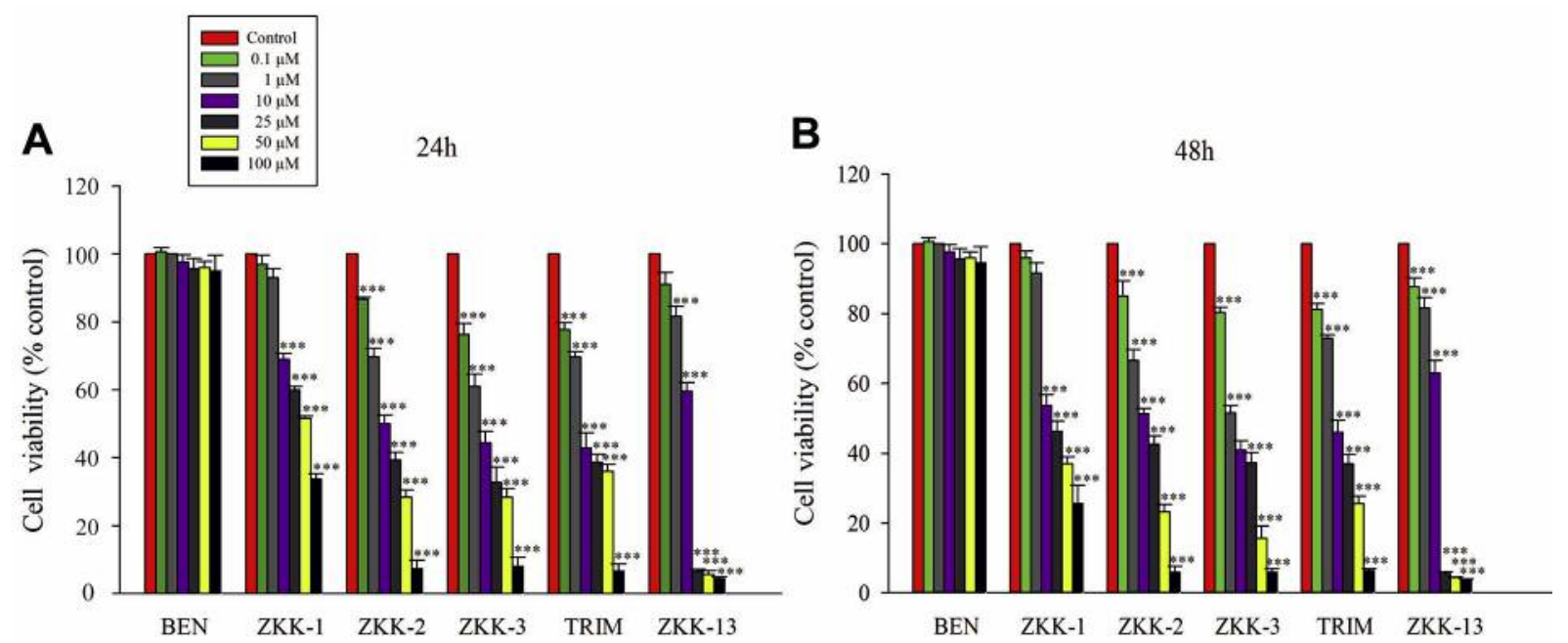

Figure 4. Effect of pentabromobenzyl isothioureas (ZKKs) and chloride-S-benzyl-isothiouronium (BEN) on the viability of T98G malignant glioma cells after (A) $24 \mathrm{~h}$ and (B) $48 \mathrm{~h}$. Metabolism assay results show that ZKKs reduced the viability of T98G glioma cells in a dose-dependent manner. Data are the mean $\pm S D$ of 9 replicates. Significantly different from the control at $* * * p<0.001$.
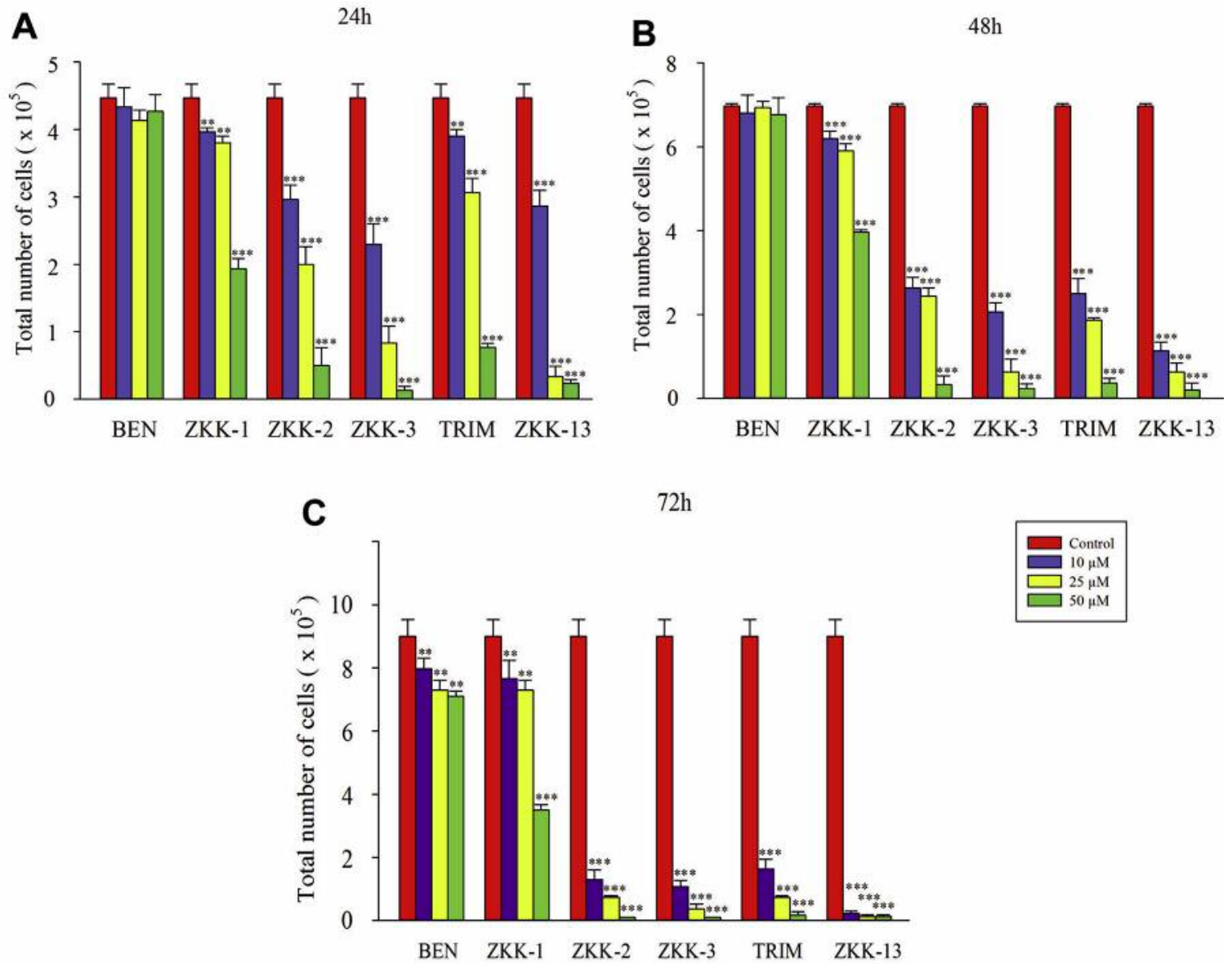

Figure 5. Effect of pentabromobenzyl isothioureas (ZKKS) and chloride-S-benzyl-isothiouronium (BEN) on the proliferation of SEGA cells after (A) $24 h,(B) 48 h$, and $(C) 72 h$ compared to untreated cultures. Data are the mean $\pm S D$ of 9 replicates. Significantly different from the control at $* * p<0.01$, and $* * * p<0.001$. 

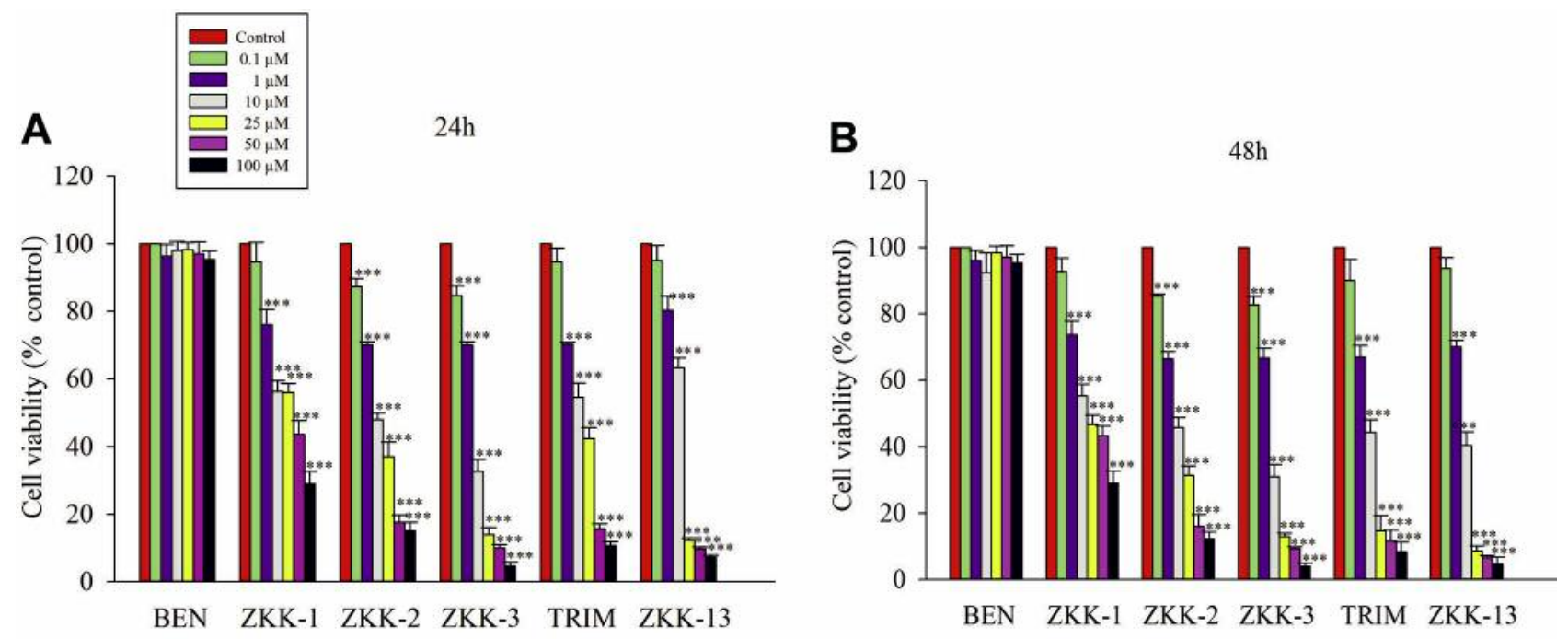

Figure 6. Effect of pentabromobenzyl isothioureas (ZKKs) and chloride-S-benzyl-isothiouronium (BEN) on the viability of SEGA cells after (A) $24 \mathrm{~h}$ and $(B) 48 \mathrm{~h}$. Data are the mean $\pm S D$ of 9 replicates. Significantly different from the control at $* * p<0.01$, and $* * * p<0.001$.
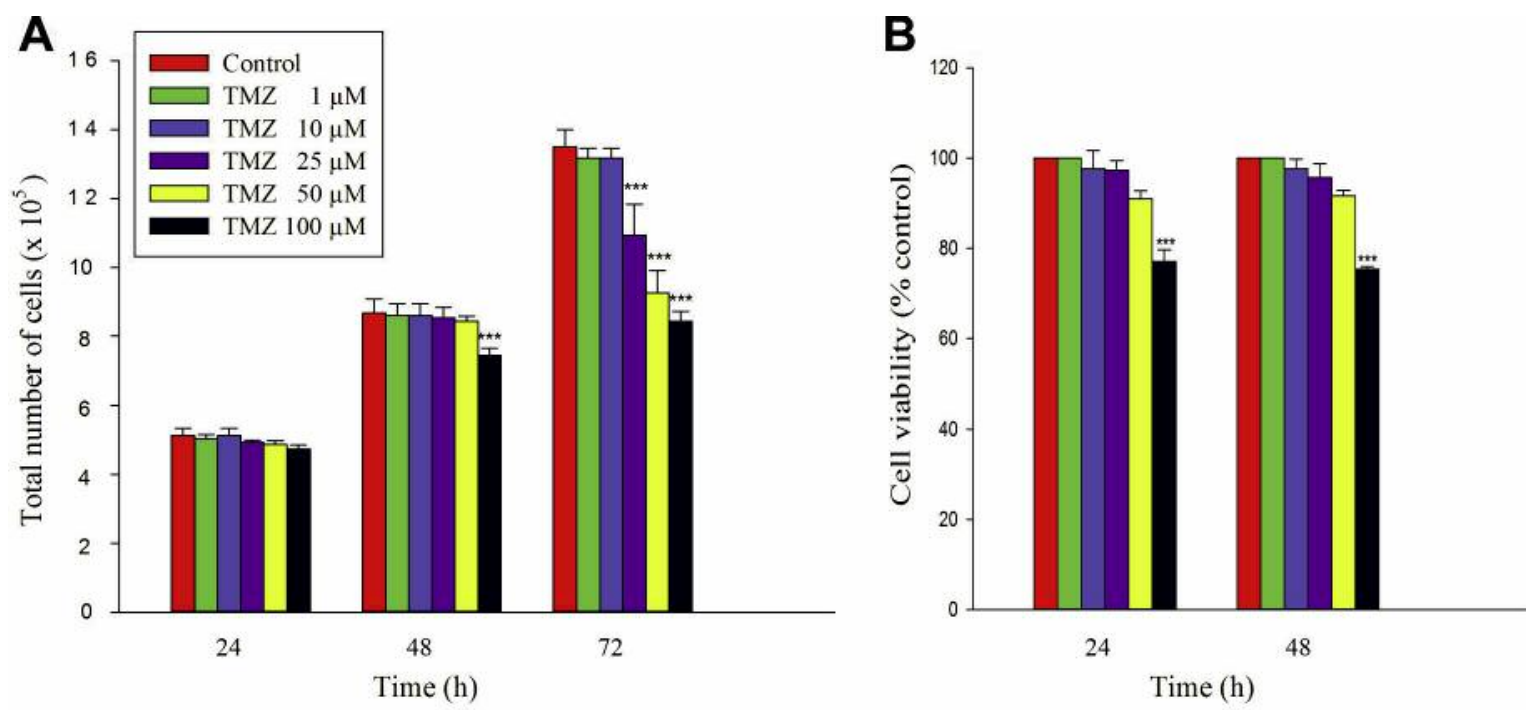

Figure 7. Effect of temozolomide (TMZ) on T98G cell line. Results are shown for cell proliferation $(A)$ and cell viability (B). Data are the mean $\pm S D$ of 9 replicates. Significantly different from the control at $* * p<0.01$, and $* * * p<0.001$.

ZKK-3, ZKK-13, and TRIM showed efficacy at 25-100 $\mu \mathrm{M}$ (Figure 6). Even a very low concentration of ZKK-2 and ZKK-3 $(0.1 \mu \mathrm{M})$ significantly reduced SEGA cell viability within $24 \mathrm{~h}$. Among the tested compounds, ZKK-3, ZKK-13, and TRIM appeared to be the most effective; at concentrations between 25 and $50 \mu \mathrm{M}$, approximately 80$90 \%$ of cells died within $24 \mathrm{~h}$ of treatment. SEGA cells were moderately resistant to BEN treatment.
Effect of temozolomide on T98G cell proliferation and viability. The cytotoxic effect of temozolomide on T98G cells was not as strong as the effect of ZKK treatment. When glioblastoma $\mathrm{T} 98 \mathrm{G}$ cells were treated with temozolomide at 10,25 , and $50 \mu \mathrm{M}$, no reduction was observed in the total number of neoplastic cells after 24 or $48 \mathrm{~h}$ (Figure 7A). At a concentration of $100 \mu \mathrm{M}$, temozolomide only a very slightly inhibited proliferation after $48 \mathrm{~h}$. After $72 \mathrm{~h}$, 

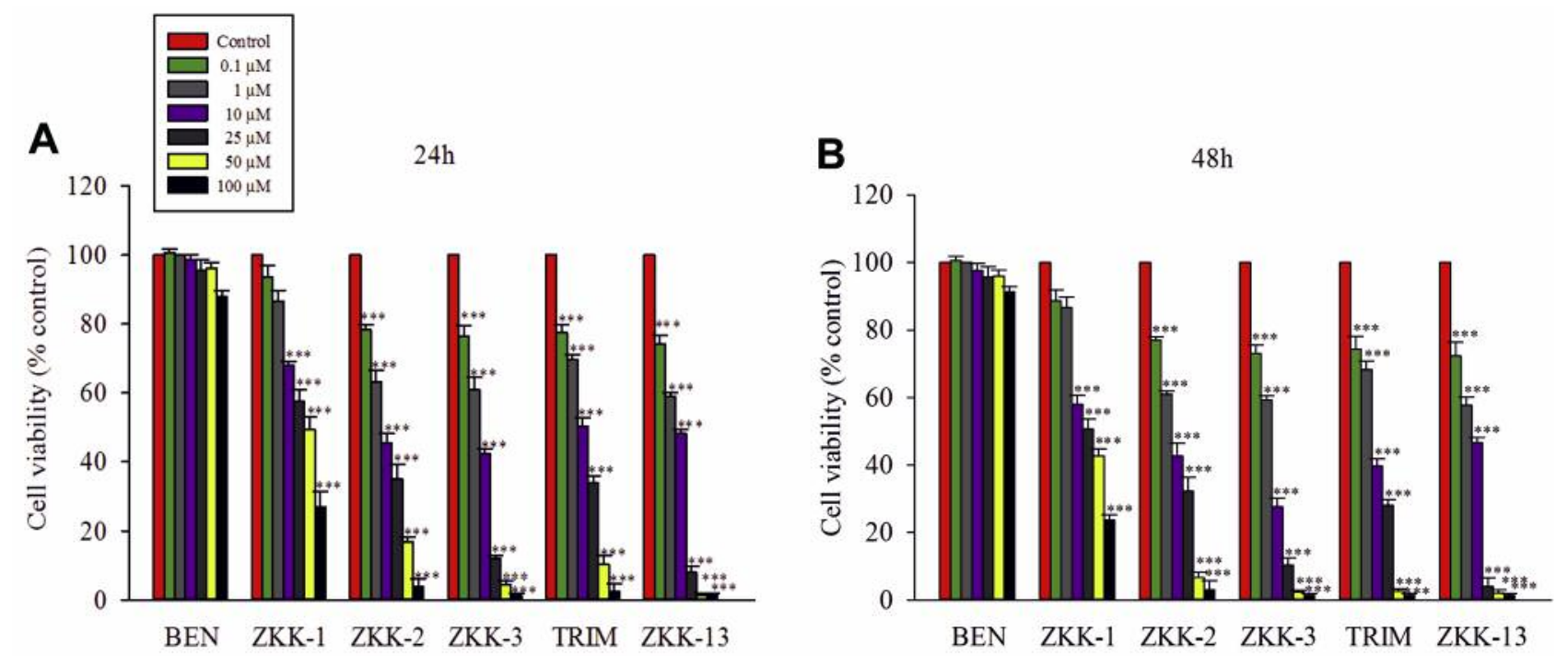

Figure 8. Effect of pentabromobenzyl isothioureas (ZKKs) and chloride-S-benzyl-isothiouronium (BEN) on the viability of a normal human astrocyte (HA) cell line after (A) $24 \mathrm{~h}$ and (B) $48 \mathrm{~h}$. Data are the mean $\pm S D$ of 9 replicates. Significantly different from the control at $* * p<0.01$, and $* * * p<0.001$.

temozolomide at 50,75 , and $100 \mu \mathrm{M}$ caused slight reductions in cell numbers, with maximum reductions of 60$80 \%$. Similarly, temozolomide inhibition of malignant glioma cell viability was noticeable only at a dose of $100 \mu \mathrm{M}$ after 24 and 48 h (Figure 7B).

Effect of ZKKs on normal astrocyte viability. ZKK-1, ZKK2, ZKK-3, ZKK-13, and TRIM treatment of normal human astrocyte cell line led to significant reductions in cell viability compared to control cells after 24 and 48 h (Figure 8).

Effect of ZKKs on T98G cell apoptosis. We performed flow cytometric analyses to study apoptosis in neoplastic cells, untreated (control culture) or treated with ZKK-1, ZKK-2, ZKK-3, or TRIM. These compounds exhibited dosedependent proapoptotic effects on the T98G malignant glioma cell line (Figure 9A and B). ZKK-2, ZKK-3, and TRIM exhibited high apoptotic activity; at $75 \mu \mathrm{M}$ and $100 \mu \mathrm{M}$, they induced apoptosis in 80-96\% of neoplastic cells after $24 \mathrm{~h}$ (Figure 9A). ZKK-3 and TRIM induced apoptosis in 96$100 \%$ of cells at $75-100 \mu \mathrm{M}$ after $48 \mathrm{~h}$ (Figure 9B).

Analysis of the respective flow cytograms (Figure 9C and D) showed that at $75 \mu \mathrm{M}$, the tested compounds induced apoptosis (early and late) of T98G cells. Among the tested compounds, ZKK-1 at $75 \mu \mathrm{M}$ also induced necrosis $(17.95 \pm 3.38 \%)$; other compounds evoked necrosis in fewer than $12 \%$ of cells. Therefore, apoptosis is the main type of cell death induced by the tested compounds.

In cultures treated with the tested compounds, a morphological study supported the findings of apoptotic changes in the glioma T98 cell line. Typical apoptotic cell morphology was observed, including cellular shrinkage, cell membrane blebbing, nuclear condensation and fragmentation, and the formation of apoptotic bodies. Electron microscopy revealed morphological features that confirmed the apoptotic mode of cell death (Figure 9E). The neoplastic cells exhibited condensed nuclear chromatin with fragmented nuclei and the formation of isolated chromatin clumps in the cytoplasm. Some cells showed a mixture of apoptotic and autophagic changes. The nucleus displayed highly condensed chromatin, and the cytoplasm exhibited advanced vacuolization and the presence of numerous primary and secondary lysosomes, typical of autophagy. At higher ZKK doses, necrotic changes were also observed. The control cell cultures exhibited neoplastic cells with abundant cytoplasm containing a well-preserved irregular nucleus or multiple nuclei and numerous intact organelles.

Effect of ZKK-3 combined with CK2 inhibitor on T98G cell viability. Cells were treated with one of two CK2 inhibitors (DMAT and TBI), applied alone or in combination with ZKK-3. Both CK2 inhibitors slightly inhibited cell viability when applied alone. However, these effects were less extensive than the effect of ZKK-3 alone. No synergistic effect was observed at either of the tested concentrations when we combined ZKK-3 with DMAT (Figure 10A and B) or TBI (Figure 10C and D) after 24 or $48 \mathrm{~h}$ of treatment.

Effect of ZKK-3 on BCL2 and PKD1 levels in T98G cells. We evaluated whether the level of the anti-apoptotic protein BCL2 
A

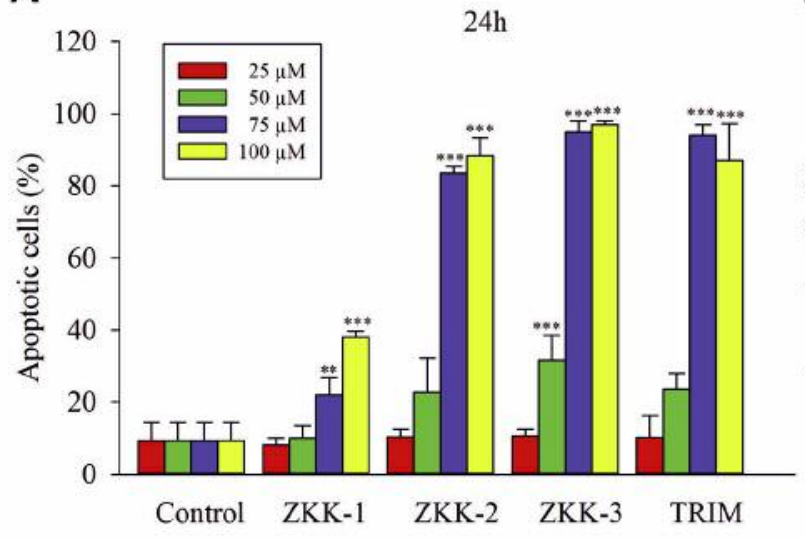

B

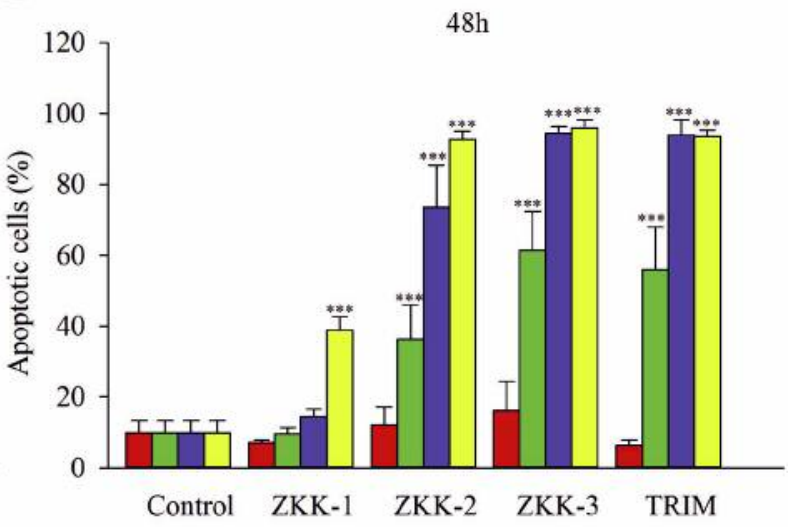

C
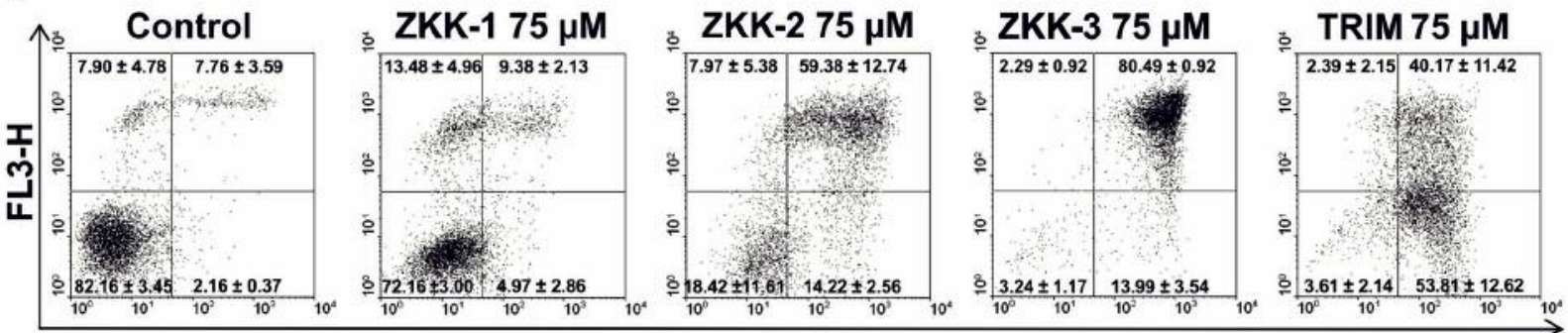

FL1-H

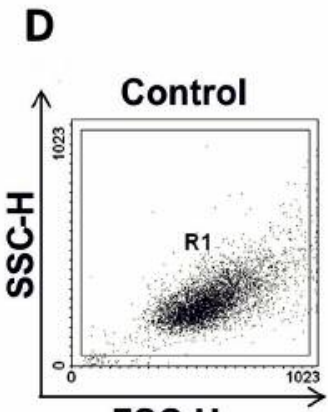

E
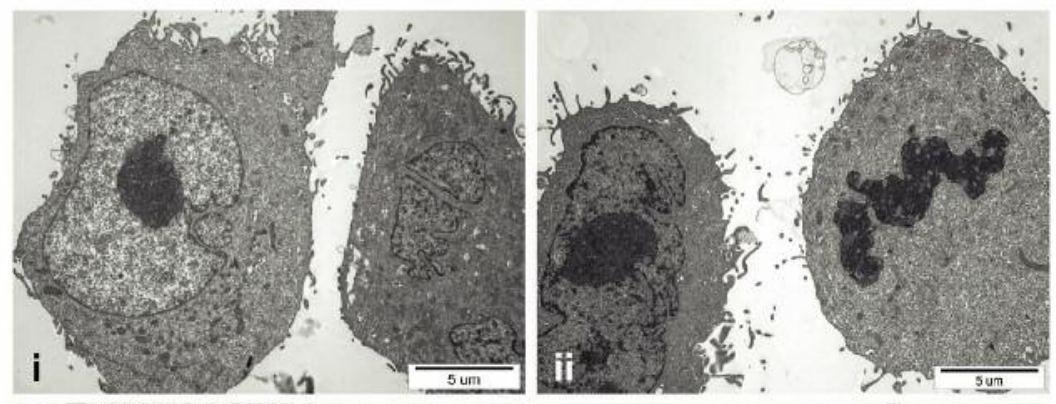

FSC-H
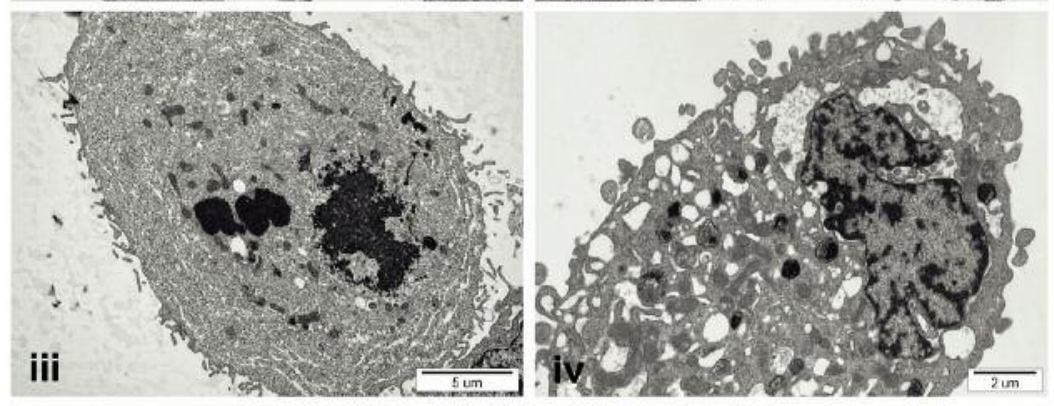

Figure 9. Flow cytometry showing the effects of pentabromobenzyl isothioureas (ZKKs) on apoptosis in the T98G cell line after $24 \mathrm{~h}$ (A) and $48 \mathrm{~h}(\mathrm{~B})$. Treatment with ZKK-1, ZKK-2, ZKK-3, and TRIM induced apoptosis compared to untreated control cells. C and D: Representative flow cytograms demonstrating the induction of apoptosis by ZKKs after exposure for $48 \mathrm{~h}$. The cells were stained with fluorescein-isothiocyanate (FITC)-conjugated annexin $V$ and propidium iodide (PI). C: The lower left quadrant (PI- and annexin V-FITC-negative) shows viable cells. The lower right quadrant (PI-negative and annexin V-FITC-positive) shows early apoptotic cells. The top right quadrant (PI- and annexin V-FITC-positive) shows late apoptotic cells. The upper left quadrant (PI-positive and annexin V-FITC-negative) shows necrotic cells (all cytograms from gate R1). D: Representative plot showing gating strategy. E: Ultrastructural features of neoplastic cells exposed to ZKKs. (i) Control T98G culture: Well-preserved neoplastic cells. (ii) T98G treated with $25 \mu M$ ZKK-3 for 24 h: Neoplastic cells with condensed nuclear chromatin typical of apoptosis. (iii) T98G treated with $50 \mu M$ ZKK-3 for 24 h: Fragmentation of nuclei and formation of isolated chromatin clumps in the cytoplasm. (iv) T98G treated with $10 \mu M$ ZKK-13 for 24 h: Neoplastic cell showing a mixture of apoptotic and autophagic changes, with highly condensed nuclear chromatin and numerous autophagic vacuoles dispersed throughout the cytoplasm. 

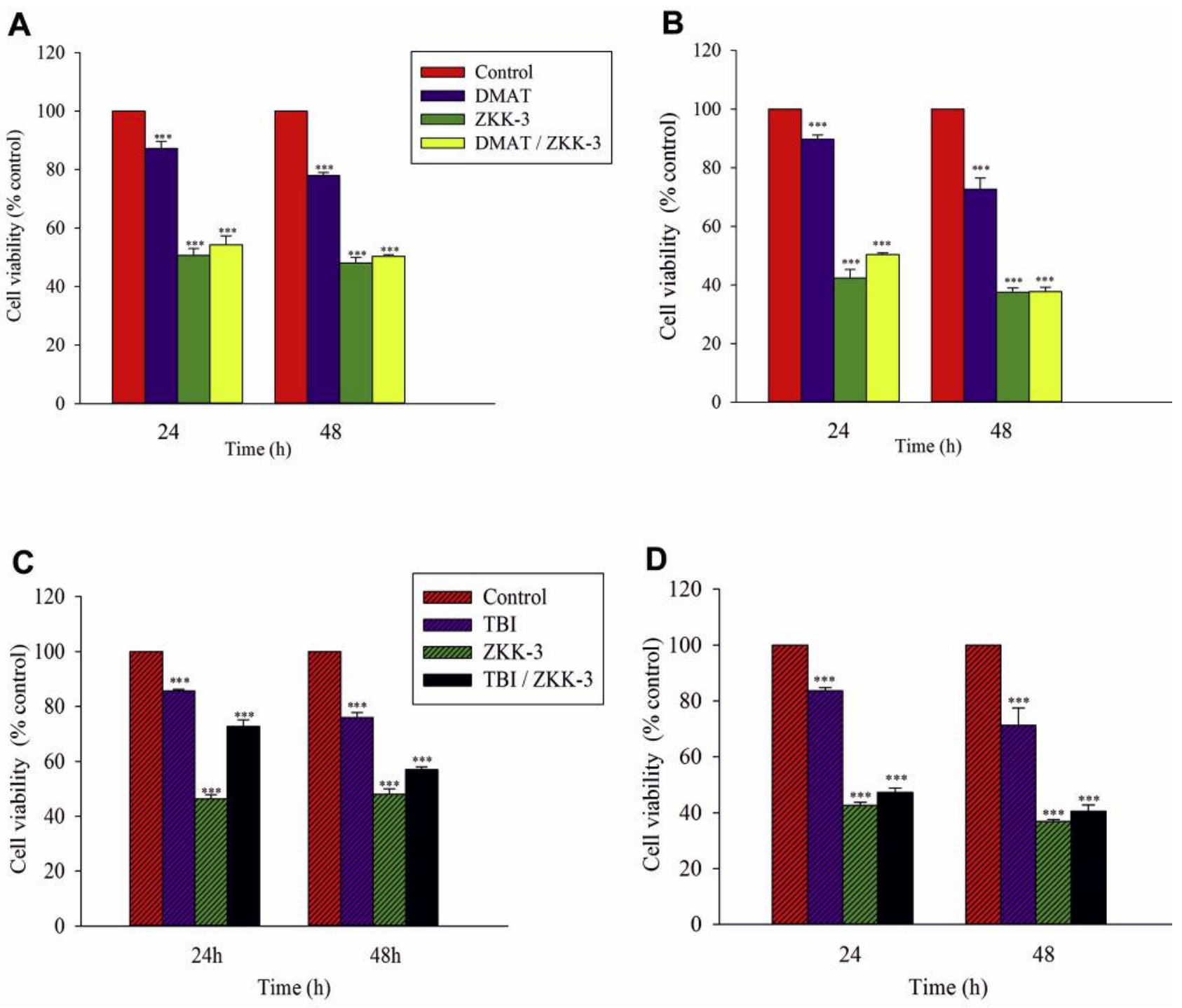

Figure 10. Effect of a pentabromobenzyl isothiourea $(Z K K-3)$ at $10(A, C)$ and $25 \mu M(B, D)$, alone and with casein kinase-2 inhibitor 2dimethylamino-4,5,6,7-tetrabromo-1H-benzimidazole (DMAT) (A, B) or 4,5,6,7-tetrabromo-1H-benzimidazole (TBI) (C, D) on T98G cell viability. No synergistic effect was observed after the combined application of ZKK-3 with either casein kinase-2 inhibitor at either concentration tested. Data are the mean $\pm S D$ of 9 replicates. Significantly different from the control at $* * p<0.01$, and $* * * p<0.001$.

was affected when cells were treated with one of the tested compounds. Western blot analyses on whole cell extracts of T98G cells cultured in the presence of ZKK-3 $(10 \mu \mathrm{M})$ for 48 $\mathrm{h}$ showed a reduction in BCL2 protein level compared to control cultures by $53.5 \%$ (Figure $11 \mathrm{~A}$ and $\mathrm{B}$ ).

Western blot analyses revealed that ZKK-3 at $10 \mu \mathrm{M}$ did not significantly affect the total PKD1 level (11.7\%) in human glioblastoma T98G cells after $48 \mathrm{~h}$ (Figure $11 \mathrm{C}$ and D), whereas it caused a reduction in the level of phosphorylated PKD1 by $66.6 \%$ in these cells (Figure 11E and F).

\section{Discussion}

The growth and proliferation of neoplastic cells is associated with the deregulation of key proteins. The pleiotropic protein kinase, CK2, composed of two catalytic (alpha or alpha') and two regulatory (beta) subunits, is considered to be involved in the regulation of many survival pathways. CK2 appears to be highly expressed in the neoplastic cells of various types of malignancies, and it plays an important role in tumour development. CK2 participates in inhibiting tumour suppressors, activating oncogenes, and maintaining a 

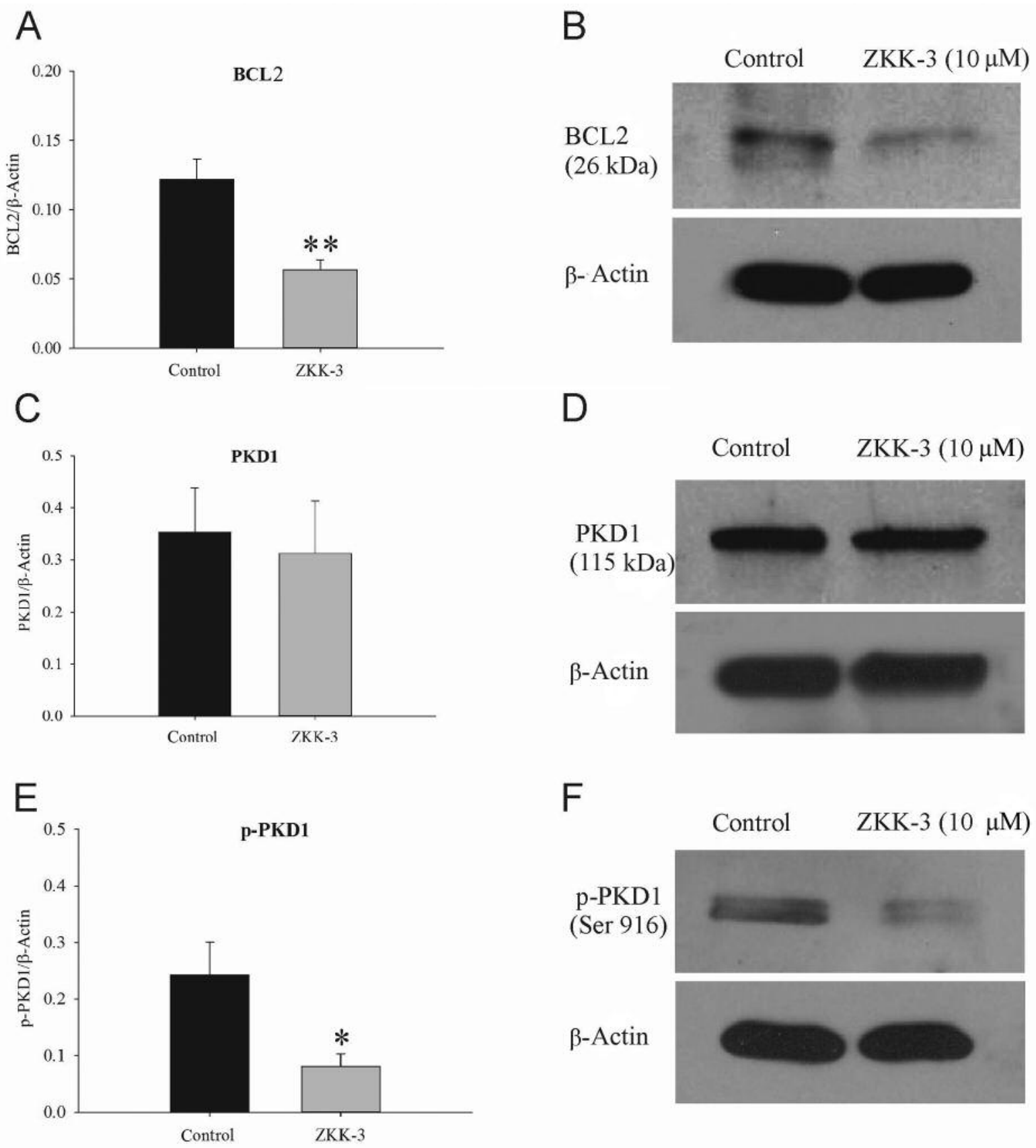

Figure 11. Western blot analysis of cell death regulator B-cell lymphoma-2 (BCL2) (A, B), protein kinase-D1 (PKD1) (C, D) and phospho (p)-PKD1 $(E, F)$ in T98G cells treated with pentabromobenzyl isothiourea ZKK-3 for $48 \mathrm{~h} . A, C, E$ : Data shown are the optical density of examined proteins normalized to that of $\beta$-actin expressed as means \pm SEM $(n=6)$. Reduction of PKD1 phosphorylation after treatment with ZKK-3 for $48 \mathrm{~h}$. Data are the mean $\pm S D$ of 9 replicates. Significantly different at $* p<0.05$ and $* * p<0.01$ compared to control.

subpopulation of cancer stem cells $(17,28-30)$. Thus, inhibitors of CK2 might be considered as a promising class of anticancer agents $(31,32)$.

Recent studies have shown CK2 to be overexpressed in glioblastoma cells, and that it regulated the survival, proliferation, and migration of astroglial neoplastic cells (33). CK2 has been implicated in the activation of many signalling pathways. Aberrant activation of the NF- $\mathrm{kB}$, PI3K/AKT, and JAK/STAT3 pathways has been implicated in the progression of human glioblastoma (33); consequently, 
CK2 expression and the effects of CK2 inhibitors have become central interests in research. The inhibition of CK2 activity, either with a selective CK2 inhibitor, such as CX4945, suppressed activation of the JAK/STAT, NF-kB, and AKT pathways and downstream gene expression in human glioblastoma xenografts (34). Azonaphthalene derivatives, a new family of highly specific CK2 inhibitors, promoted cellcycle arrest in human glioblastoma U373 cells, and the U373 cell tumour mass was reduced by $83 \%$ (35). Moreover, down-regulation of CK2 induced cell death through the modulation of the signalling pathways in human glioblastoma cells (36); in that study, glioblastoma cells died because CK2 down-regulation prevented tumour resistance to multiple anticancer agents.

Recently, novel isothiourea derivatives have attracted growing interest, due to their structural similarity to CK2 inhibitors, particularly the polybrominated benzene part of these molecules. Accordingly, it was hypothesized that the biological activity of ZKKs may be related to their ability to inhibit protein kinases. Furthermore, it is reasonable to assume that structural modifications of these compounds might modify their cellular effects. To address these hypotheses, the inhibitory properties of ZKK-3 were previously tested on a large panel of protein kinases. That study showed that this representative ZKK agent effectively inhibited seven protein kinases: PIM1, PIM3, IGF1R, ERK8, PKD1, NEK2a, and the IR. All these kinases are important for cell survival and for the proper functioning of both normal and neoplastic cells (20). Among these kinases, PKD1 has been increasingly implicated in multiple biological and molecular events that regulate tumour proliferation or invasion in many cancer types (37-41). However, little is known about the expression and function of PKD1 in malignant primary brain tumours of astroglial origin. In the current study, we demonstrated that ZKK-3 moderately inhibited PKD1 activity in the T98G human glioblastoma cell line. This finding supports the suggestion that the mechanism of anticancer activity of $\mathrm{ZKKs}$ is related to protein kinase inhibition.

However, it should be mentioned that ZKKs have also been shown to be potent inhibitors of nitric oxide synthase (NOS), which is involved in a variety of physiological and pathological events (42-46). In particular, S-ethylisothiourea was established as a potent, selective, competitive inhibitor of human NOS (47).

The potential beneficial effects of isothiourea derivatives have been widely studied in experimental models of different pathological states. A variety of positive pharmacological effects have been associated with isothiourea derivatives, including anti-hepatitis-C virus activity (48-50), hypoglycaemic properties $(51,52)$, antibacterial efficacy $(53-$ $55)$ and neuroprotective effects $(56,57)$. Moreover, ZKKs exhibit anticancer properties. In previous studies, the effects of ZKKs were tested on several neoplastic cell lines, including human prostate adenocarcinoma (20), HL-60 promyelocytic leukemia and K-562 human chronic erythromyeloblastoid leukemia cell line $(58,59)$. However, only one previous report investigated ZKK efficacy against brain malignancies; they studied cultured C6 rat glioma cells and two human highgrade glioma cell lines, LN229 (astrocytoma, WHO grade III) and T98G (glioblastoma, WHO grade IV). That report indicated that isothioureas that carried a methyl or dimethyl (ZKK-2/-3) and those that carried a short alkyl or allyl group (ZKK-4/-5) exhibited effective cytotoxic effects on neoplastic glial cells in vitro (22).

In the current study, we demonstrated that ZKKs exert cytotoxic and proapoptotic activities against human astroglial neoplastic cells in vitro. We also showed that ZKKs reduce growth and cell viability of both high-grade malignant glioblastoma cells and low grade SEGA cells. SEGA is generally a benign and slow growing WHO grade I tumour of astrocytic nature which occurs in patients with tuberous sclerosis complex. SEGA is composed of large ganglioid cells with a wide range of astroglial phenotypes. It is currently classified as a tumour of astroglial origin (60). However, SEGA cells also exhibit features suggestive of neuronal differentiation $(61,62)$; therefore, we might consider these tumours to be of mixed glio-neuronal lineage $(61,63,64)$. Nevertheless, the astroglial component of SEGA is welldifferentiated, and this component is responsible for the lowgrade malignancy. We used SEGA cultures to study the cytotoxicity of the tested compounds in a benign glioma. We showed that ZKKs induced a reduction in the total cell number in both T98G and SEGA-derived cell lines after $24 \mathrm{~h}$ and $72 \mathrm{~h}$ of treatment; in addition, ZKKs effectively reduced neoplastic cell viability. We found that ZKK-2, ZKK3, ZKK-13, and TRIM displayed potent growth inhibition, even at very low concentrations $(1 \mu \mathrm{M})$. ZKK-13 appeared to be the most potent antiproliferative agent, reducing cell viability by $80-90 \%$ when applied at $10 \mu \mathrm{M}$.

We also found that an isothiourea with a chlorine substitute on the phenyl ring (BEN) exerted little or no cytotoxic activity. It was previously established that, among various isothiourea-derived salts, only (S)-2,3,4,5,6pentabromobenzyl isothiouronium chlorides had equivalent nitrogen sites (65). Our results support the suggestion that this unique structural feature of ZKKs could be related to their high biological activity.

Of note, we showed that temozolamide at 10,25, and $50 \mu \mathrm{M}$ exhibited only slight cytotoxic effects on T98G cells. A previous report documented that temozolomide effectively induced apoptosis and necrosis in the T98G human glioblastoma line, but only at concentrations above $100 \mu \mathrm{M}$ (66). Thus, ZKKs, particularly ZKK-13 and TRIM, are far more potent than temozolamide. Temozolamide is often used as a reference drug in malignant glioma therapy because it has become an important agent in combined radio- and 
chemotherapy for newly diagnosed glioblastomas in patients with a methylated promoter in the O6-methylguanine-DNA methyltransferase gene (67-69).

Previous studies demonstrated that low micromolar concentrations of novel ZKKs (ZKK-1 to ZKK-5) induced concentration-dependent, proapoptotic effects on HL-60 and K-562 human leukaemia cell lines (21). These effects may be related to $\mathrm{CK} 2$ inhibition because CK2 is known to suppress apoptosis. Our in vitro data showed that novel ZKKs exhibited significant proapoptotic efficacy in cultured neoplastic astroglial cells. Flow cytometry and transmission electron microscopy were used to evaluate the mode of cell death and confirmed it to be through apoptosis. Moreover, western blot analysis demonstrated reduction of BCL2 protein level. Thus, we conclude that the cytotoxic effects of the tested compounds are related to their proapoptotic properties.

A previous report showed that a combination of CK2 inhibitors and ZKKs induced synergistic anti-leukemic effects in KG-1 acute myelogenous leukaemia cells (58). Moreover, selected ZKKs, alone or in combination with CK2 inhibitors, showed anticancer activities in prostate, leukaemia, and glioblastoma cell lines. However, we did not find any enhancement in the antiproliferative effect of ZKK-3 on the T98G cell line when combined with either TBI or DMAT.

\section{Conclusion}

The present study showed that certain novel ZKKs exhibited potent antiproliferative and proapoptotic efficacy against cultured neoplastic astroglial cells. We found that ZKKs strongly inhibited neoplastic cell growth of both high- and low-grade tumours of astrocytic lineage. Moreover, this was the first study to demonstrate that ZKKs had antitumour efficacy in SEGA cells in vitro. Our results established that very low concentrations $(1 \mu \mathrm{M})$ of two isothiourea derivates, ZKK-13 and TRIM, exhibited potent cytotoxic and proapoptotic efficacies against glioma-derived cultures. However, ZKKs also induced cytotoxic effects in normal astrocytes in vitro. In the future, this therapeutically-negative effect might be eliminated with modern techniques of drug delivery. Fortunately, the human brain structure allows local application of cytostatic compounds; however, the therapeutic strategy should be chosen considering the activities of ZKKs

Our findings also indicate that the isothiourea scaffold structure may be exploited in future studies to discover more specific drugs for treating malignant gliomas. Based on our results, ZKKs showed promise as an anticancer therapy, including for the treatment of glioma-derived primary brain tumours. Our findings, that the effects of ZKKs and CK2 inhibitors were not enhanced when administered together, indicated that combinations of these compounds should not be recommended to achieve synergistic therapeutic effects in glioma treatments.

\section{Source of Funding}

The research was partly supported by the Foundation for the Development of Diagnostic and Therapy.

\section{Conflicts of Interest}

All Authors have no conflict of interest in regard to this study.

\section{References}

1 Diamandis P and Aldape KD: Insights from molecular profiling of adult glioma. J Clin Oncol 35: 2386-2393, 2017.

2 Karsy M, Guan J, Cohen AL, Jensen RL and Colman H: New molecular considerations for glioma: IDH, ATRX, BRAF, TERT, H3 K27M. Curr Neurol Neurosci Rep 17: 19, 2017.

3 Wirsching HG, Galanis E and Weller M: Glioblastoma. Handb Clin Neurol 134: 381-397, 2016.

4 Louis D, Von Deimling A and Cavenee WK: Diffuse astrocytic and oligodendrogliual tumours. In: WHO Classification of Tumors of the Central Nervous System. Louis DN, Oghaki H, Wiesttler D, Wiestler OD and Cavenee WK (eds.). Lyon, IARC Press., pp. 15-78, 2016.

5 Zhang $\mathrm{X}$, Zhang $\mathrm{W}$, Cao WD, Cheng $\mathrm{G}$ and Zhang YQ: Glioblastoma multiforme: Molecular characterization and current treatment strategy (Review). Exp Ther Med 3: 9-14, 2012.

6 Dunn GP, Rinne ML, Wykosky J, Genovese G, Quayle SN, Dunn IF, Agarwalla PK, Chheda MG, Campos B, Wang A, Brennan C, Ligon KL, Furnari F, Cavenee WK, Depinho RA, Chin L and Hahn WC: Emerging insights into the molecular and cellular basis of glioblastoma. Genes Dev 26: 756-784, 2012.

7 Karsy M, Huang T, Kleinman G and Karpel-Massler G: Molecular, histopathological and genomic variants of glioblastoma. Front Biosci (Landmark Ed) 19: 1065-1087, 2014.

8 Bleeker FE, Molenaar RJ and Leenstra S: Recent advances in the molecular understanding of glioblastoma. J Neurooncol 108: 11-27, 2012.

9 Toms SA and Tapinos N: Recent advances in the treatment of gliomas-comprehensive brain tumor center. R I Med J (2013) 100: 43-46, 2017.

10 Cloughesy TF, Cavenee WK and Mischel PS: Glioblastoma: from molecular pathology to targeted treatment. Annu Rev Pathol 9: 1-25, 2014.

11 Golub AG, Bdzhola VG, Ostrynska OV, Kyshenia IV, Sapelkin VM, Prykhod'ko AO, Kukharenko OP and Yarmoluk SM: Discovery and characterization of synthetic 4'-hydroxyflavonesNew CK2 inhibitors from flavone family. Bioorg Med Chem 21: 6681-6689, 2013.

12 Guillon J, Le Borgne M, Rimbault C, Moreau S, Savrimoutou S, Pinaud N, Baratin S, Marchivie M, Roche S, Bollacke A, Pecci A, Alvarez L, Desplat V and Jose J: Synthesis and biological evaluation of novel substituted pyrrolo[1,2a]quinoxaline derivatives as inhibitors of the human protein kinase CK2. Eur J Med Chem 65: 205-222, 2013.

13 Hou Z, Nakanishi I, Kinoshita T, Takei Y, Yasue M, Misu R, Suzuki Y, Nakamura S, Kure T, Ohno H, Murata K, Kitaura K, Hirasawa A, Tsujimoto G, Oishi S and Fujii N: Structure-based design of novel potent protein kinase CK2 (CK2) inhibitors with phenyl-azole scaffolds. J Med Chem 55: 2899-2903, 2012. 
14 Hundsdorfer C, Hemmerling HJ, Gotz C, Totzke F, Bednarski P, Le Borgne $\mathrm{M}$ and Jose $\mathrm{J}$ : Indeno[1,2-b]indole derivatives as a novel class of potent human protein kinase CK2 inhibitors. Bioorg Med Chem 20: 2282-2289, 2012.

15 Chua MM, Ortega CE, Sheikh A, Lee M, Abdul-Rassoul H, Hartshorn KL and Dominguez I: CK2 in cancer: cellular and biochemical mechanisms and potential therapeutic target. Pharmaceuticals 10, 2017. doi 10.3390/ph10010018.

16 Ortega CE, Seidner Y and Dominguez I: Mining CK2 in cancer. PLoS One 9: e115609, 2014.

17 Cozza G, Pinna LA and Moro S: Protein kinase CK2 inhibitors: a patent review. Expert Opin Ther Pat 22: 1081-1097, 2012.

18 Rabalski AJ, Gyenis L and Litchfield DW: Molecular Pathways: Emergence of protein kinase CK2 (CSNK2) as a potential target to inhibit survival and dna damage response and repair pathways in cancer cells. Clin Cancer Res 22: 2840-2847, 2016.

19 Zhou Y, Li K, Zhang S, Li Q, Li Z, Zhou F, Dong X, Liu L, Wu $\mathrm{G}$ and Meng R: Quinalizarin, a specific CK2 inhibitor, reduces cell viability and suppresses migration and accelerates apoptosis in different human lung cancer cell lines. Indian J Cancer 52(Suppl 2): e119-124, 2015.

20 Koronkiewicz M, Kazimierczuk Z, Szarpak K and Chilmonczyk Z: Proapoptotic effects of new pentabromobenzylisothiouronium salts in a human prostate adenocarcinoma cell line. Acta Pol Pharm 69: 1325-1333, 2012.

21 Koronkiewicz M, Chilmonczyk Z and Kazimierczuk Z: Proapoptotic effects of novel pentabromobenzylisothioureas in human leukemia cell lines. Med Chem Res 21: 3111-3118, 2012.

22 Kaminska B, Ellert-Miklaszewska A, Oberbek A, Wisniewski P, Kaza B, Makowska M, Bretner M and Kazimierczuk Z: Efficacy and mechanism of anti-tumor action of new potential CK2 inhibitors toward glioblastoma cells. Int J Oncol 35: 1091-1100, 2009.

23 LaValle CR, George KM, Sharlow ER, Lazo JS, Wipf P and Wang QJ: Protein kinase D as a potential new target for cancer therapy. Biochim Biophys Acta 1806: 183-192, 2010.

24 Biswas MH, Du C, Zhang C, Straubhaar J, Languino LR and Balaji KC: Protein kinase D1 inhibits cell proliferation through matrix metalloproteinase-2 and matrix metalloproteinase-9 secretion in prostate cancer. Cancer Res 70: 2095-2104, 2010.

25 Guha S, Tanasanvimon S, Sinnett-Smith J and Rozengurt E: Role of protein kinase D signaling in pancreatic cancer. Biochem Pharmacol 80: 1946-1954, 2010.

26 Andrzejewska M, Pagano MA, Meggio F, Brunati AM and Kazimierczuk Z: Polyhalogenobenzimidazoles: synthesis and their inhibitory activity against casein kinases. Bioorg Med Chem 11: 3997-4002, 2003.

27 Tyburczy ME, Kotulska K, Pokarowski P, Mieczkowski J, Kucharska J, Grajkowska W, Roszkowski M, Jozwiak S and Kaminska B: Novel proteins regulated by mTOR in subependymal giant cell astrocytomas of patients with tuberous sclerosis complex and new therapeutic implications. Am J Pathol 176: 1878-1890, 2010.

28 Pierre F, Regan CF, Chevrel MC, Siddiqui-Jain A, Macalino D, Streiner N, Drygin D, Haddach M, O'Brien SE, Rice WG and Ryckman DM: Novel potent dual inhibitors of CK2 and PIM kinases with antiproliferative activity against cancer cells. Bioorg Med Chem Lett 22: 3327-3331, 2012.

29 Prins RC, Burke RT, Tyner JW, Druker BJ, Loriaux MM and Spurgeon SE: CX-4945, a selective inhibitor of casein kinase-2 (CK2), exhibits anti-tumor activity in hematologic malignancies including enhanced activity in chronic lymphocytic leukemia when combined with fludarabine and inhibitors of the B-cell receptor pathway. Leukemia 27: 2094-2096, 2013.

30 Wang X, Pan P, Li Y, Li D and Hou T: Exploring the prominent performance of CX-4945 derivatives as protein kinase CK2 inhibitors by a combined computational study. Mol Biosyst 10: 1196-1210, 2014.

31 Sun H, Xu X, Wu X, Zhang X, Liu F, Jia J, Guo X, Huang J, Jiang Z, Feng T, Chu H, Zhou Y, Zhang S, Liu Z and You Q: Discovery and design of tricyclic scaffolds as protein kinase CK2 (CK2) inhibitors through a combination of shape-based virtual screening and structure-based molecular modification. J Chem Inf Model 53: 2093-2102, 2013.

32 Zanin S, Borgo C, Girardi C, O’Brien SE, Miyata Y, Pinna LA, Donella-Deana A and Ruzzene M: Effects of the CK2 inhibitors CX-4945 and CX-5011 on drug-resistant cells. PLoS One 7: e49193, 2012.

$33 \mathrm{Ji} \mathrm{H}$ and Lu Z: The role of protein kinase CK2 in glioblastoma development. Clin Cancer Res 19: 6335-6337, 2013.

34 Zheng Y, McFarland BC, Drygin D, Yu H, Bellis SL, Kim H, Bredel $\mathrm{M}$ and Benveniste EN: Targeting protein kinase CK2 suppresses prosurvival signaling pathways and growth of glioblastoma. Clin Cancer Res 19: 6484-6494, 2013.

35 Moucadel V, Prudent R, Sautel CF, Teillet F, Barette C, Lafanechere L, Receveur-Brechot V and Cochet C: Antitumoral activity of allosteric inhibitors of protein kinase CK2. Oncotarget 2: 997-1010, 2011.

36 Olsen BB, Svenstrup TH and Guerra B: Downregulation of protein kinase CK2 induces autophagic cell death through modulation of the mTOR and MAPK signaling pathways in human glioblastoma cells. Int J Oncol 41: 1967-1976, 2012.

37 Ni Y, Wang L, Zhang J, Pang Z, Liu Q and Du J: PKD1 is downregulated in non-small cell lung cancer and mediates the feedback inhibition of mTORC1-S6K1 axis in response to phorbol ester. Int J Biochem Cell Biol 60: 34-42, 2015.

38 Shabelnik MY, Kovalevska LM, Yurchenko MY, Shlapatska LM, Rzepetsky Y and Sidorenko SP: Differential expression of PKD1 and PKD2 in gastric cancer and analysis of PKD1 and PKD2 function in the model system. Exp Oncol 33: 206-211, 2011.

39 Sundram V, Chauhan SC and Jaggi M: Emerging roles of protein kinase D1 in cancer. Mol Cancer Res 9: 985-996, 2011.

40 Sundram V, Ganju A, Hughes JE, Khan S, Chauhan SC and Jaggi M: Protein kinase D1 attenuates tumorigenesis in colon cancer by modulating beta-catenin/T cell factor activity. Oncotarget 5: 6867-6884, 2014.

41 Zhang K, Ye C, Zhou Q, Zheng R, Lv X, Chen Y, Hu Z, Guo H, Zhang Z, Wang Y, Tan R and Liu Y: PKD1 inhibits cancer cells migration and invasion via Wnt signaling pathway in vitro. Cell Biochem Funct 25: 767-774, 2007.

42 Southan GJ, Szabo C and Thiemermann C: Isothioureas: potent inhibitors of nitric oxide synthases with variable isoform selectivity. Br J Pharmacol 114: 510-516, 1995.

43 Handy RL, Wallace P and Moore PK: Inhibition of nitric oxide synthase by isothioureas: cardiovascular and antinociceptive effects. Pharmacol Biochem Behav 55: 179-184, 1996.

44 Wang Y, Lawson JA and Jaeschke H: Differential effect of 2aminoethyl-isothiourea, an inhibitor of the inducible nitric oxide synthase, on microvascular blood flow and organ injury in models of hepatic ischemia-reperfusion and endotoxemia. Shock 10: 20-25, 1998. 
45 Paesano N, Marzocco S, Vicidomini C, Saturnino C, Autore G, De Martino G and Sbardella G: Synthesis and biological evaluation of 3-benzyl-1-methyl- and 1-methyl-3-phenylisothioureas as potential inhibitors of iNOS. Bioorg Med Chem Lett 15: 539-543, 2005.

46 Vromen A, Szabo C, Southan GJ and Salzman AL: Effects of Sisopropyl isothiourea, a potent inhibitor of nitric oxide synthase, in severe hemorrhagic shock. J Appl Physiol 81: 707-715, 1996.

47 Garvey EP, Oplinger JA, Tanoury GJ, Sherman PA, Fowler M, Marshall S, Harmon MF, Paith JE and Furfine ES: Potent and selective inhibition of human nitric oxide synthases. Inhibition by non-amino acid isothioureas. J Biol Chem 269: 26669-26676, 1994.

48 Kang IJ, Wang LW, Lee CC, Lee YC, Chao YS, Hsu TA and Chern JH: Design, synthesis and anti-HCV activity of thiourea compounds. Bioorg Med Chem Lett 19: 1950-1955, 2009.

49 Sharma A, Gupta SP and Siddiqui AA: A QSAR study on a series of thiourea derivatives acting as anti-hepatitis $\mathrm{C}$ virus agents. Indian J Biochem Biophys 50: 278-283, 2013.

50 Kang IJ, Wang LW, Yeh TK, Lee CC, Lee YC, Hsu SJ, Wu YS, Wang JC, Chao YS, Yueh A and Chern JH: Synthesis, activity and pharmacokinetic properties of a series of conformationallyrestricted thiourea analogs as novel hepatitis $\mathrm{C}$ virus inhibitors. Bioorg Med Chem 18: 6414-6421, 2010.

51 Zhang HB, Zhang YA, Wu GZ, Zhou JP, Huang WL and Hu $\mathrm{XW}$ : Synthesis and biological evaluation of sulfonylurea and thiourea derivatives substituted with benzenesulfonamide groups as potential hypoglycemic agents. Bioorg Med Chem Lett 19: 1740-1744, 2009

52 Maruyama T, Seki N, Onda K, Suzuki T, Kawazoe S, Hayakawa M, Matsui T, Takasu T and Ohta M: Discovery of novel thiourea derivatives as potent and selective beta3-adrenergic receptor agonists. Bioorg Med Chem 17: 5510-5519, 2009.

53 Kupchik EJ, Pisano MA, Raghunath AV, Cardona RA, Formaini $\mathrm{N}$ and Alleguez C: Synthesis and antimicrobial activity of $\mathrm{N}$ substituted N'-cyano-S-(triorganostannyl)isothioureas. J Pharm Sci 64: 1259-1262, 1975.

54 Kazimierczuk Z, Chalimoniuk M, Laudy AE, Moo-Puc R, Cedillo-Rivera R, Starosciak BJ and Chrapusta SJ: Synthesis and antimicrobial and nitric oxide synthase inhibitory activities of novel isothiourea derivatives. Arch Pharm Res 33: 821-830, 2010.

55 Sunduru N, Srivastava K, Rajakumar S, Puri SK, Saxena JK and Chauhan PM: Synthesis of novel thiourea, thiazolidinedione and thioparabanic acid derivatives of 4-aminoquinoline as potent antimalarials. Bioorg Med Chem Lett 19: 2570-2573, 2009.

56 Perlovich GL, Proshin AN, Volkova TV, Kurkov SV, Grigoriev $\mathrm{VV}$, Petrova LN and Bachurin SO: Novel isothiourea derivatives as potent neuroprotectors and cognition enhancers: synthesis, biological and physicochemical properties. J Med Chem 52: 1845-1852, 2009

57 ArunaDevi R, Ramteke VD, Kumar S, Shukla MK, Jaganathan S, Kumar D, Sharma AK and Tandan SK: Neuroprotective effect of S-methylisothiourea in transient focal cerebral ischemia in rat. Nitric Oxide 22: 1-10, 2010.

58 Koronkiewicz M, Chilmonczyk $\mathrm{Z}$ and Kazimierczuk Z: Synergistic anti-leukemic effects of CK2 inhibitors and pentabromobenzylisothioureas in vitro. Anticancer Res 33: 4891$4899,2013$.
59 Koronkiewicz M, Zukowska M, Chilmonczyk Z, Orzeszko A and Kazimierczuk Z: Synthesis and proapoptotic properties of new casein kinase II inhibitors. Acta Pol Pharm 67: 635-641, 2010.

60 Lopes M, Wiestler O, Stemmmer-Rachamimov A, Sharma M, Vinters H and Santosh V: Subependymal giant cell astrocytoma. In: WHO Classification of Tumors of the Central Nervous System. Louis DN, Oghaki H, Wiesttler D, Wiestler OD, Cavenee WK (eds.). Lyon, IARC Press., pp. 90-93, 2016.

61 Buccoliero AM, Franchi A, Castiglione F, Gheri CF, Mussa F, Giordano F, Genitori L and Taddei GL: Subependymal giant-cell astrocytoma (SEGA): Is it an astrocytoma? Morphological, immunohistochemical and ultrastructural study. Neuropathology 29: 25-30, 2009

62 Jozwiak J, Jozwiak S and Skopinski P: Immunohistochemical and microscopic studies on giant cells in tuberous sclerosis. Histol Histopathol 20: 1321-1326, 2005.

63 Goh S, Butler W and Thiele EA: Subependymal giant-cell tumors in tuberous sclerosis complex. Neurology 63: 1457-1461, 2004.

64 Nakamura Y and Becker LE: Subependymal giant-cell tumor: astrocytic or neuronal? Acta Neuropathol 60: 271-277, 1983.

65 Latosinska JN, Latosinska M, Seliger J, Zagar V, Maurin JK and Kazimierczuk Z: Nature of isomerism of solid isothiourea salts, inhibitors of nitric oxide synthases, as studied by $1 \mathrm{H}-14 \mathrm{~N}$ nuclear quadrupole double resonance, X-ray and density functional theory/quantum theory of atoms in molecules. J Phys Chem A 116: 1445-1463, 2012.

66 Jakubowicz-Gil J, Langner E, Badziul D, Wertel I and Rzeski $\mathrm{W}$ : Apoptosis induction in human glioblastoma multiforme T98G cells upon temozolomide and quercetin treatment. Tumour Biol 34: 2367-2378, 2013.

67 Stupp R, Hegi ME, Mason WP, van den Bent MJ, Taphoorn MJ, Janzer RC, Ludwin SK, Allgeier A, Fisher B, Belanger K, Hau P, Brandes AA, Gijtenbeek J, Marosi C, Vecht CJ, Mokhtari K, Wesseling P, Villa S, Eisenhauer E, Gorlia T, Weller M, Lacombe D, Cairncross JG, Mirimanoff RO, European Organisation for R, Treatment of Cancer Brain $\mathrm{T}$, Radiation Oncology $\mathrm{G}$ and National Cancer Institute of Canada Clinical Trials G: Effects of radiotherapy with concomitant and adjuvant temozolomide versus radiotherapy alone on survival in glioblastoma in a randomised phase III study: 5-year analysis of the EORTC-NCIC trial. Lancet Oncol 10: 459-466, 2009.

68 Stupp R, van den Bent MJ and Hegi ME: Optimal role of temozolomide in the treatment of malignant gliomas. Curr Neurol Neurosci Rep 5: 198-206, 2005.

69 Hegi ME, Diserens AC, Godard S, Dietrich PY, Regli L, Ostermann S, Otten P, Van Melle G, de Tribolet N and Stupp R: Clinical trial substantiates the predictive value of O-6methylguanine-DNA methyltransferase promoter methylation in glioblastoma patients treated with temozolomide. Clin Cancer Res 10: 1871-1874, 2004

Received January 29, 2018

Revised March 13, 2018

Accepted March 20, 2018 